\title{
Bartolomeu Valeriu Anania și reeducarea de la Aiud. Noi contribuții documentare: dosarele Securității
}

Dragoș URSU*

Abstract: The paper proposes to analyse the activity of Bartolomeu Anania in the context of the Aiud re-education, an episode that created controversy in the memorialistic literature of the Romanian Gulag. The paper will exclusively use documents from the Securitate archives, excerpts from the files of Bartolomeu Anania, of other prisoners, as well as files belonging to the Aiud Operative Group. The role of the article is to provide researchers and the public with new documentary sources that help understand the topic of the Aiud reeducation. Regarding the activity of Bartolomeu Anania in the reeducation, as shown by the Securitate documents, we notice the marginal role he had, limited to the public reading of the "self-unmasking" declarations, in the imposed pattern of the re-education clubs' meetings; also noticeable are Anania's discussions with Ilie Niculescu regarding the tense relationship between Christianity and the legionary movement and, towards the end of re-education, his minimal contribution (a fourpage material on Corneliu Codreanu) to the "Book of the Re-education".

Keywords: Securitate archives, memorialistic literature of the Romanian Gulag, the Aiud Operative Group, Christianity and the Legionary movement.

* Doctor în istorie și muzeograf în cadrul Muzeului Național al Unirii din Alba Iulia, România. 


\section{Introducere}

Destinul mitropolitului Bartolomeu Anania se confundă cu istoria Bisericii Ortodoxe în perioada contemporană, începând din anii '40 și până la trecerea acestuia la Domnul în anul 2011. Relaţia Bisericii cu Mișcarea Legionară, al doilea Război Mondial, începuturile comunizării, patriarhatul lui Justinian Marina, redimensionarea relației stat-Biserică în perioada comunistă, viața monahală din anii ' 50 , represiunea împotriva Bisericii, destinderea din anii '60-'70, diaspora ortodoxă, patriarhatul lui Justin Moisescu, căderea comunismului, tranziția din anii ' 90 și revigorarea vieții religioase, toate acestea sunt fenomene și evenimente istorice de prim plan din viața Bisericii Ortodoxe în care Bartolomeu Anania a fost implicat, în ipostaze și cu roluri diferite.

Personalitatea sa puternică și pozițiile de prim plan avute în viaţa Bisericii (arhiepiscop și mitropolit al Clujului) 1-au adus pe Bartolomeu Anania în atenția opiniei publice, notorietate care s-a tradus şi prin controverse inerente legate de anumite episoade din biografia lui, precum activitatea în cadrul Episcopiei Misionare din America (1965-1976), sau poziția față de fenomenul reeducării din penitenciarul Aiud.

Intriga acestei analize o reprezintă controversele care învăluie activitatea lui Bartolomeu Anania în cadrul reeducării, controverse create la nivelul unui fragment din memoria-memorialistica Gulagului. Întâi de toate, se impun precizate cu strictețe limitele acestei analize, care nu-şi propune să radiografieze/investigheze în amănunt „tensiunile memoriale” create în jurul activităţii din reeducare a lui Bartolomeu Anania, subiect care va fi abordat într-o cercetare ulterioară. Astfel, precizarea „pozițiilor memoriale” în partea introductivă a articolului are doar rolul de a familiariza cititorul cu ,intriga” acestui demers.

Întâi de toate, trebuie menționat faptul că „tensiunile memoriale" își au originea în episodul american al biografiei lui Bartolomeu Anania: pe când activa în cadrul episcopiei dependente de Patriarhia Română, Anania se afla pe poziții distincte (uneori 
Bartolomeu Valeriu Anania și reeducarea de la Aiud.

Noi contribuții documentare: dosarele Securității

adverse) față de episcopia condusă de Valerian Trifa, care aduna cea mai mare parte a exilului legionar.

Folosind ca „,surse primare” lucrările lui Ion Cârja ${ }^{1}$, Nistor Chioreanu $^{2}$, Octavian Voinea ${ }^{3}$, Puiu Năstase ${ }^{4}$, memorialiști precum Ion Antohe ${ }^{5}$, Aurel Sergiu Marinescu ${ }^{6}$ și Grigore Caraza ${ }^{7}$ îi creează un portret negativ lui Bartolomeu Anania, căruia îi atribuie un rol central în reeducarea de la Aiud. Cel din urmă, Grigore Caraza, ajuns în exilul american legionar abia în 1980 și influenţat de polemicile târzii dintre cele două tabere, este principalul „creator” al discursului incriminator la adresa lui Bartolomeu Anania, pe care îl acuză, compilând informații de la Ion Cârja și Nistor Chioreanu, că a primit de la colonelul Crăciun ,mână liberă să conducă reeducările"". De asemenea, supralicitând referința lui Nistor Chioreanu, Grigore Caraza îl desemnează pe Bartolomeu Anania drept autorul „cărții reeducării”, unde „dădea în sinteză despre reeducările din perioada 1960-1964, în calitate de șef al acestor „activități cultural-educative"

Un ultim aspect relevant referitor la ,tensiunile memoriale”, care merită subliniat, este faptul că Demostene Andronescu, unul din memorialiștii consacrați ai reeducării de la Aiud, nu menționează numele lui Bartolomeu Anania în lucrarea sa cu valențe monografice ${ }^{10}$.

${ }^{1}$ Ion CÂRJA, Amintiri din infern, vol. 1 și 2, New York, Acțiunea românească, 1972.

${ }^{2}$ Nistor Chioreanu, Morminte vii, Iași, Edit. Institutul European, 1992.

3 Octavian VoINEA, Masacrarea studenții române în închisorile de la Pitești, Gherla și Aiud, București, Edit. Majadahonda, 1996.

${ }^{4}$ Puiu CĂLINESCU, Temerarii, Constanța, Edit. Metafora, 2004.

5 Ion AntoHe, Răstigniri în România după Ialta, București, Edit. Albatros, 1995.

6 Aurel Sergiu Marinescu, O contribuție la istoria exilului românesc. Biserica Ortodoxă Română în străinătate, în exil, în diaspora, București, Edit. Vremea, 2004.

${ }^{7}$ Grigore CARAZA, Aiud însângerat, Iași, Edit. TipoMoldova, 2013.

${ }^{8}$ Ibidem, f. 144.

${ }^{9}$ Ibidem, f. 146.

${ }^{10}$ Demostene Andronescu, Reeducarea de la Aiud, Bucureşti, Edit. Christiana, 2009. 
În ceea ce privește depozițiile lui Bartolomeu Anania despre propria activitate în cadrul reeducării (Memoriile ${ }^{l 1}$ și alte scrieri cu valoare memorialistică $\breve{a}^{12}$ ), acestea sunt bine-cunoscute publicului larg și cercetătorilor, și nu vor reprezenta, din cauza spațiului limitat, o miză analitică a articolului. În scrierile sale memorialistice dedicate Aiudului, Bartolomeu Anania se concentrează asupra creațiilor literare compuse în detenție, precum Meșterul Manole și Steaua Zimbrului. În privința reeducării, Bartolomeu Anania amintește de propria autoanaliză ținută la clubul din secția IX $\mathrm{TBC}^{13}$, condus de Nicolae Grigorescu, de discuția cu Ilie Niculescu în jurul incompatibilităţii dintre creștinism și legionarism ${ }^{14}$, de opoziția față de încercarea regimului de a organiza și o reeducare „religioasă”, în care deținuții ar fi fost obligați să-și abjure

${ }^{11}$ Valeriu AnANIA, Memorii, Iași, Edit. Polirom, 2008.

12 Capitolul Dumnezeu în temniță, în Mitropolitul Bartolomed, Coruptia spirituală, ediție îngrijită de Radu Preda și Bogdan Ivanov, Cluj-Napoca, Edit. Eikon, 2011.

13 „Mă hotărâsem să mă aşez pe poziția nu a omului politic ci a teologului, şi să-mi motivez neaderența la ML prin incompatibilitatea dintre ideologia și faptele ei, pe de o parte, și învățătura creștină, pe de alta. $\mathrm{O}$ asemenea paralelă nu se putea face fără ample incursiuni în Biblie și în Sfinții Părinți. Grigorescu părea interesat, dar asesorii au obiectat - iritați că la adăpostul autoanalizei propagam religia în penitenciar. Terminasem ce avusesem de spus - din toată treaba aceea - care a durat vreo trei zile - numai exorcismele mi-au fost penibile și le-am făcut $a$ contre-coeur - cu inima neîmpăcată - să faci fără să ai chef - am revenit la treburile mele.", Valeriu ANANIA, Memorii, p. 328-329.

14 „Niculescu voia să știe foarte multe asupra adevăratelor raporturi dintre creștinism și Mișcarea Legionară - de altfel vechi subiect de controversă în toate mediile politice și bisericești - şi $\mathrm{m}$-a iscodit zile și săptămâni întregi, cu o nepotolită sete de cunoaștere. Îmi dădeam perfect de bine seama că-l duceam pe acest om spre clătinarea și prăbuşirea crezurilor lui de peste 30 de ani și n-aş fi vrut să fiu un iconoclast, dar nici nu puteam să-i vorbesc împotriva propriilor mele convingeri, pe care le nutream, și eu, de două decenii. Mai mult, intelectul rafinat al lui Niculescu mi-a dat prilejul să adâncesc aceste probleme până la cele mai delicate subtilităţi. Începând să priceapă, el se înspăimânta la gândul că atât amar de vreme fusese, în realitate, un necredincios. L-a liniștit - și luminat doar distincția pe care i-am oferit-o între noțiunile de bine-credincios şi răucredincios. Dar în afară de aceasta am avut cu el lungi și interesante dialoguri de filozofie, literatură și artă. Ne-am legat și am rămas prieteni.”, Ibidem, f. 330. 
Bartolomeu Valeriu Anania și reeducarea de la Aiud.

Noi contribuții documentare: dosarele Securității

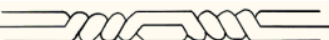

credința $^{15}$, şi de contribuţia minimală pe care ar fi avut-o la redactarea „cărţii reeducării”'16.

Pornind de la această intrigă, a imaginii controversate a lui Bartolomeu Anania în memoria(listica) reeducării de la Aiud, obiectivul articolului este a contribui la înțelegerea subiectului prin utilizarea exclusivă a unor surse inedite, precum dosarele Securității (dosare aparținând lui Bartolomeu Anania ${ }^{17}$, altor deținuți ${ }^{18}$, dar și dosare de fond Documentar ${ }^{19}$ ale Grupului Operativ Aiud - unitatea de Securitate care a coordonat reeducarea de la Aiud), cu scopul de a pune la dispoziția publicului și cercetătorilor noi izvoare istorice.

$\mathrm{Nu}$ în ultimul rând, un aspect fundamental care trebuie menţionat în partea introductivă este cel legat de perspectiva „moralistă” asupra fenomenului reeducării, în speță evaluarea „vinovăției” deținuților în funcție de gradul de implicare în reeducare. Considerăm această perspectivă de ,tribunal al memoriei" depăşită și periculoasă atât din punct de vedere moral, cât și istoric. Întâi de toate, pentru că istoricul nu e un judecător al trecutului, cu atât mai mult în cazul unor evenimente traumatice precum reeducările din Gulagul românesc. Mai mult decât atât, perspectiva „moralistă” e o capcană în sine, de care regimul

15 „La o întâlnire cu Crăciun, am căutat să-l conving că nu e în interesul lor să împingă reeducarea pe o asemenea pantă. Dacă, mai greu sau mai ușor, oamenii și-au renegat trecutul politic, nu vor glumi deloc în ceea ce privește credința lor religioasă - singurul bun care le-a mai rămas și care, după convingerea mea, nu are nimic de-a face cu Garda de Fier", Ibidem, f. 331.

16 „Acolo (clubul condus de Stere Mihalexe n.n.) i-am cunoscut și auzit pe Nicolae Petraşcu, Radu Mironovici, Nistor Chioreanu alcătuiau un fel de document funebru al Mișcării Legionare. Treceam drept scriitor și Nicolae Petrașcu m-a rugat să-i ajut la stilizare, ceea ce am făcut cu ceva mai multă silă decât gratuitate.", Ibidem, f. 332.

17 Arhiva Consiliului Național pentru Studierea Arhivelor Securităţii (ACNSAS): Anania Valeriu - fond Informativ, dosar 888, dosar 930, dosar 1450 (5 vol.);

18 Anania Dumitru - fond Informativ, dosar 491900 (2 vol.); Chioreanu Nistor fond Informativ, dosar 233979 (10 vol.); Niculescu Ilie - fond Informativ, dosar 375778 (5 vol.);

${ }^{19}$ Fond Documentar, dosarele 8826 (3 vol.), 10160 (2 vol.), 12163, 12581, 12609 (6 vol.), 13088, 13341 (2 vol.), 13481, 13482 (6 vol.), 13483 (3 vol.), 13484 (14 vol.), 13485 (15 vol.). 
comunist s-a folosit pentru a-i compromite pe deținuţi tocmai pentru faptul că au luat parte la reeducare.

În mod cinic, colonelul Crăciun a exploatat „onoarea suferinței”, la care deținuții legionari țineau atât mult, Grupul Operativ urmărind cu consecvență să anihileze acest „,patrimoniu memorial”. Însuși termenul „cădere/a căzut”, atât de intens utilizat în memorialistică referitor la deținuții care au ,acceptat”, reeducarea, trădează o perspectivă politică asupra fenomenului concentraționar, deoarece, în cazul reeducării de la Aiud se referă la „căderea” față de Mișcarea Legionară, respectiv ,abjurarea” apartenenței la această organizație.

De altfel, situaţia României comuniste, în anii reeducării (1959-1964), era cu totul alta decât la momentul când cei mai mulți deținuți fuseseră arestați (sfârșitul anilor '40). La începutul anilor '60, regimul comunist era pe deplin instaurat și se bucura de un anumit suport popular, astfel că, pentru orice minte lucidă, posibilitatea reluării activității legionare era de-a dreptul utopică.

Sintetizând, chiar cu riscul caricaturizării, se poate afirma că o perspectivă „moralistă” asupra reeducării s-ar traduce prin evaluarea „vinovăției” unor deținuţi care, după ani grei de închisoare și la presiunea unui regim stabil și puternic, au renunţat la identitatea legionară și și-au asumat încadrarea în noua ordine social-politică. Desuetudinea și ipocrizia morală a unei astfel de poziționări se impune de la sine.

Din perspectivă „morală”, singura posibilă responsabilitate care poate fi chestionată, dar care nu e de competența istoricului (căruia nu-i rămâne decât să o investigheze și reconstituie nuanțat), este cea referitoare la rolul de ,reeducator-demascator” al celorlalți deținuți, pe care și 1-au asumat unii dintre cei implicaţi în reeducare. Dar, și în cazul acestora, singurii îndreptățiți să judece și să se poziționeze moral sunt doar foștii deținuţi politici.

Detaşându-se de aceste perspective politico-moraliste cu accente ideologice, istoricului nu-i rămâne decât să încerce să înțeleagă şi explice reeducarea de la Aiud în contextul general al mecanismelor represive puse în mișcare de către regimul comunist. 
Bartolomeu Valeriu Anania și reeducarea de la Aiud.

Noi contribuții documentare: dosarele Securității

\section{Reeducarea de la Aiud}

Reacția comuniștilor de la București față de revoluția din Ungaria (noiembrie 1956) s-a tradus printr-o politică represivă de amploare care urmărea eliminarea oricăror forme de opoziție, reale sau imaginare, faţă de regim. În acest context s-a încadrat și decizia „reeducării” deținuților politici, în general, și a celor legionari, în particular. În cazul penitenciarului Aiud, conducerea MAI i-a rezervat o „misiune” specială, respectiv ,reeducarea legionarilor" ${ }^{20}$, proces care încheia fenomenul reeducărilor din sistemul concentraționar comunist.

Pentru succesul procesului reeducării desfășurat între anii 19591964, regimul a investit masiv, deopotrivă la nivel uman, instituțional şi material. Astfel, la conducerea penitenciarului este adusă o nouă echipă, formată din tineri ofițeri de Securitate, în fruntea cărora se afla experimentatul colonel Gheorghe Crăciun. Se construiește un nou cadru instituțional, Grupul Operativ Aiud, asimilat unei regionale de Securitate, condus de colonelul Crăciun, și care avea ca principal obiectiv coordonarea reeducării deținuților legionari ${ }^{21}$. Procesul decizional este, de asemenea, restructurat, Grupul Operativ ieșind de sub autoritatea Regionalei de Securitate Cluj, pe raza căreia se afla penitenciarul, şi fiind coordonat de către conducerea Ministerului de Interne $^{22}$, ministrul Alexandru Drăghici implicându-se direct în procesul reeducării prin vizitele făcute în penitenciar ${ }^{23}$.

Scopurile reeducării ${ }^{24}$, din perspectiva regimului, au fost deopotrivă politice și umane: destrămarea organizației legionare și anihilarea capacității acesteia de a relua activitatea politică după eliberare; desolidarizarea deținuţilor legionari de trecutul politic și asumarea publică a încadrării în noul regim; ,autoflagelarea" politică și personală și, nu în ultimul rând, compromiterea morală a deținuților tocmai prin participarea la reeducare.

${ }^{20}$ ACNSAS, fond Documentar, dosar 13485, vol. 13, f. 158.

${ }^{21}$ ACNSAS, fond Informativ, dosar 261871, vol. 1, f. 78 .

${ }^{22}$ ACNSAS, fond Documentar, dosar 7368, ff. 487-491.

${ }^{23}$ ACNSAS, fond Documentar, dosar 13484, vol. 2, f. 73.

${ }^{24}$ ACNSAS, fond Documentar, dosar 3463, f. 46. 
Pentru succesul misiunii, Grupul Operativ a desfăşurat o muncă informativă intensă în rândul deținuților, utilizând resurse umane (informatori) și materiale (tehnică operativă) ${ }^{25}$, cu scopul documentării detaliate a activității cotidiene a acestora. Munca informativă a reprezentat ,motorul” reeducării, prin care Grupul Operativ a cunoscut poziția deținuților și a coordonat reeducarea.

În privința reeducării, denumită eufemistic în documente „muncă cultural-educativă”, Grupul Operativ şi-a structurat eforturile pe două planuri: în primul rând, s-a focalizat asupra liderilor legionari, care au fost supuși unor presiuni constante (anchete, șantaje, demascări, izolări) pentru a accepta reeducarea; un rol decisiv în procesul de reeducare a liderilor legionari 1-a avut Victor Biriș, principalul agent de influență al Securității în rândul deținuților $^{26}$. În al doilea rând, în ceea ce privește reeducarea deținuților „obișnuiți”, fără grade sau funcții în organizația legionară, Grupul Operativ a desfăşurat o muncă cultural-educativă mai puțin intensă, urmărind în primul rând desolidarizarea acestora de organizația legionară și acceptarea încadrării în noul regim.

La nivelul metodelor, Grupul Operativ a utilizat un instrumentar divers, care a integrat deopotrivă ,,persuasiunea ideologică" (activitatea culturală la club, bibliografia marxistă, filmele de propagandă), presiunea psihologică (demascări, șantaje, anchete) și măsurile coercitive (izolarea în Zarcă, înfometarea). O strategie cu un impact puternic în rândul deținuților a fost ,popularizarea" realizărilor regimului ${ }^{27}$, atât prin intermediul documentarelor/jurnalelor tv difuzate în cadrul ședințelor de club, dar mai ales prin excursiile organizate cu unii lideri legionari prin țară (București, Valea Prahovei, Cluj, Hunedoara). Prin acest demers, Grupul Operativ a reușit să argumenteze deţinuţilor soliditatea sistemului comunist, care se bucura de sprijin popular, spulberând, astfel, speranțele celor închiși în prăbușirea regimului.

${ }^{25}$ ACNSAS, fond Documentar, dosar 13341, vol. 1, ff. 63-67.

26 Recrutat în martie 1961. ACNSAS, fond Informativ, dosar 310004, vol. 2, f. 147.

27 ACNSAS, fond Documentar, dosar 13483, vol. 1, f. 246, dosar 13484, vol. 5, f. 87 şi ACNSAS, fond Documentar, dosar 13485, vol. 15, f. 166. 
Bartolomeu Valeriu Anania și reeducarea de la Aiud.

Noi contribuții documentare: dosarele Securității

În ceea ce privește „succesul” reeducării, acesta merită analizat pe cele două planuri, politic și uman. Obiectivul politic al reeducării, respectiv destrămarea organizației legionare și anihilarea posibilității reluării activismului politic după eliberare de către legionari, a fost îndeplinit cu succes. Prin „capitularea” principalilor lideri legionari (Nicolae Petrașcu, Nistor Chioreanu, Ion Dumitrescu Borșa, Radu Mironovici) care s-au ,autoflagelat” politic, condamnând legionarismul și îndemnând deținuții să accepte integrarea în noul regim, Grupul Operativ a reușit compromiterea morală a acestora. Reeducarea acestor lideri a reprezentat, de altfel, direcția de urmat pentru majoritatea deținuților, cu sau fără grade și funcții în organizația legionară, care au înțeles că, din punct de vedere politic, destinul acesteia s-a încheiat, iar reluarea activității legionare după eliberare e o himeră ideologică.

Pe de altă parte, la nivel uman, reeducarea nu s-a bucurat de același succes. $\mathrm{Cu}$ excepția câtorva deținuți cu destine traumatice, dintre care se evidențiază Victor Biriș, majoritatea covârșitoare a celor închisi nu au asumat reeducarea la nivelul convingerilor personale. În acest sens, se impune disocierea între „reeducarea” formală, manifestată prin participarea la ședințele de club, și convertirea ideologică reală. Altfel spus, reeducarea nu i-a convertit pe deținuţi din legionari în comunişti.

„Insuccesul” reeducării la nivel personal este evidențiat și de cei aproape 150 de deținuți care au refuzat ${ }^{28}$, sub orice formă, participarea la munca cultural-educativă. Între aceștia se evidențiază categoria „misticilor”, a deținuților care se detașaseră de lupta politică și își asumaseră deschis identitatea creștină ${ }^{29}$. Aceștia, majoritatea din grupul ,refractarilor”, erau considerați de către Grupul Operativ, în mod paradoxal, mai periculoși decât deținuții care afirmau deschis ,că sunt și rămân legionari”.

Un ultim aspect relevant care merită subliniat este faptul că Grupul Operativ a fost interesat, dincolo de succesul reeducării, de raportarea acestui succes către conducerea Ministerului de Interne

${ }^{28}$ ACNSAS, fond Documentar, dosar 13485, vol. 15, f. 226.

${ }^{29}$ ACNSAS, fond Documentar, dosar 12609, vol. 6, f. 78. 
şi a Partidului Muncitoresc Român. În acest sens, colonelul Crăciun sintetizează întreaga activitate a Grupului Operativ la nivelul unui raport final al reeducării, în care elogiază într-o manieră propagandistică îndeplinirea misiunii încredinţate. De asemenea, alături de raportarea „succesului” către conducerea Ministerului, Grupul Operativ a fost interesat și de utilizarea propagandistică a acestui „succes”, coordonând redactarea unor lucrări ce conțineau declarații auto-demascatoare ale deținuţilor, volume ce puteau fi utilizate împotriva exilului românesc, în general, și a organizaţiei legionare conduse de Horia Sima, în special.

Cea mai importantă astfel de lucrare, cu impact la nivel memorial, a fost „Cartea reeducării”, intitulată „Despre organizația legionară”. Structurată în două volume, cu primul dedicat istoriei Mișcării Legionare, iar cel de-al doilea activităţii din detenție a legionarilor (în special reeducării de la Aiud), lucrarea, la a cărei elaborare au contribuit 135 de deținuți ${ }^{30}$, reprezintă o sinteză stilizată a declarațiilor din cadrul cluburilor reeducării. Cartea, ce numără 826 de pagini, are o copertă realizată ,,artistic" pe care sunt gravate cuvintele „Crimă, jaf, trădare, spionaj” ${ }^{31}$. Elaborarea acestei lucrări urmărea două obiective majore: pe de o parte, reprezenta „medalia victoriei” pentru Grupul Operativ, care putea ilustra conducerii Ministerului de Interne și regimului succesul reeducării, iar pe de altă parte, era un instrument de șantaj pentru deținuții legionari și în special a ,autorilor”, a căror contribuție la „,succesul” reeducării putea fi probat.

\section{Poziția lui Bartolomeu Anania în reeducare. Contribuții documentare}

Arestat în iunie $1958^{32}$, Bartolomeu Anania ajunge, după condamnarea din aprilie 1959 la 25 de ani muncă silnică ${ }^{33}$ și după un periplu prin temnițele Jilava, Ploiești și Pitești, în temuta

\footnotetext{
${ }^{30}$ Ibidem, f. 225.

${ }^{31}$ Ibidem.

${ }^{32}$ ACNSAS, fond Informativ, dosar 1450, vol. 1, f. 2.

${ }^{33}$ Ibidem, f. 396.
} 
Bartolomeu Valeriu Anania și reeducarea de la Aiud.

Noi contribuții documentare: dosarele Securității

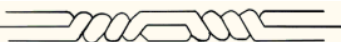

închisoare a Aiudului, în luna octombrie $1960^{34}$. Sursele documentare referitoare la detenția lui Bartolomeu Anania în Aiud sunt destul de lacunare ${ }^{35}$ și, aparent paradoxal, se găsesc în alte dosare/fonduri și mai puțin în dosarul lui personal. Deși Bartolomeu Anania a fost urmărit intens de-a lungul anilor ' $50^{36}$, Securitatea îi închide, la momentul arestării, dosarul de urmărire informativă, care va fi redeschis după eliberarea din închisoare, respectiv toamna anului $1964^{37}$. Astfel, pe toată perioada detenţiei, Bartolomeu Anania nu a făcut obiectul unei acțiuni de urmărire informativă, acest lucru explicându-se și prin faptul că el nu a fost considerat un personaj relevant pentru Grupul Operativ Aiud, care s-a focalizat, în cei cinci ani ai reeducării, asupra liderilor legionari și a deținuților cu influență, pentru cercetarea cărora a deschis câteva sute de dosare de urmărire informativă $\breve{a}^{38}$.

${ }^{34}$ Fișa matricolă penală - Valeriu Anania - https://www.iiccmer.ro/fise-matricolenou/?drawer=Fise \%20matricole $\% 20$ penale $\% 20$ -

$\% 20$ Personalitati\%20publice*Anania\%20Valeriu\%20V (accesat la 1 iulie 2020).

35 În mod firesc, cercetarea nu-și asumă epuizarea tuturor posibilelor surse documentare referitoare la activitatea lui Bartolomeu Anania în reeducarea de la Aiud. Pentru a putea trage o concluzie „deplină” ar trebui cercetate integral dosarelor celor peste 4000 de deținuți care au trecut prin Aiud în perioada reeducării. De-a lungul cercetărilor doctorale, am studiat dosarele a peste 60 de deținuți care au trecut prin penitenciarul Aiud, deopotrivă figuri cunoscute ale memoriei Gulagului, lideri legionari, preoți sau „deținuți obișnuiți”. În ceea ce privește activitatea Grupului Operativ Aiud, am studiat următoarele dosare, cu o valoare documentară substanțială: Documentar 3463 (42 file), D 8825 (14 file), D 8826 - vol. 1 (46 file), vol. 2 (30 file), vol. 3 (12 file), D 10160 - vol. 1 (460 file), vol. 2 (372 file), D 12163 (256 file), D 12581 ( 37 file), D 12609 - vol. 1 (225 file), vol. 2 (74 file), vol. 3 (300 file), vol. 4 (159 file), vol. 5 (231 file), vol. 6 (246 file), D 13341 - vol. 1 (442 file), vol. 2 (83 file), D 13481 (134 file), D 13482 - vol. 1 (442 file), vol. 2 (242 file), vol. 3 (571 file), vol. 4 (214 file), vol. 5 (217 file), vol. 6 (465), D 13483 - vol. 1 (293 file), vol. 2 (255 file), vol. 3 (370 file), D 13484 - vol. 1 (158 file), vol. 2 (222 file), vol. 3 (157 file), vol. 4 (304 file), vol. 5 (191 file), vol. 6 (192 file), vol. 7 (253 file), vol. 8 (153), vol. 9 (240 file), vol. 10 (274 file), vol. 11 (241 file), vol. 12 (197 file), vol. 13 (291 file), vol. 14 (189 file), D 13485 - vol. 10 (322 file), vol. 15 (309 file).

${ }^{36}$ ACNSAS, fond Informativ, dosar 1450, vol, 1, 1A, 2, passim.

${ }^{37}$ Ibidem, vol. 1, f. 392.

${ }^{38}$ ACNSAS, fond Documentar, dosar 12609, vol. 6, f. 80. 
Rezumând referințele la activitatea lui Bartolomeu Anania, până în acest stadiu al cercetării, cele mai relevante informații se regăsesc în dosarele Grupului Operativ ${ }^{39}$ și în cel de urmărire informativă a lui Ilie Niculescu ${ }^{40}$.

Singura mențiune ,relevantă” din dosarul de urmărire informativă al lui Bartolomeu Anania referitoare la poziția sa în reeducarea de la Aiud o constituie caracterizarea semnată de colonelul Crăciun la eliberarea din detenție (august 1964):

„În detenție până în 1963 s-a menţinut pe o poziție de ostilitate față de regimul nostru, iar în munca cultural-educativă a avut rezerve. Începând din 1963 și-a schimbat atitudinea devenind un element combativ în demascarea activității organizaţiei legionare și a șefilor ei. În prezent este folosit la munci interioare unde depune un interes deosebit. TBC pulmonar stabilizat ${ }^{41}$ ".

Caracterizarea, lacunară și paradoxală în același timp, reprezintă intriga demersului nostru de reconstituire, analiza propunându-și să sondeze ce s-a petrecut în 1963, când Bartolomeu Anania își „schimbă” poziția, precum și activitatea lui ulterioară în reeducare.

Până în 1963, mențiunile despre Bartolomeu Anania sunt lapidare. Astfel, aflăm că în septembrie 1962 se afla în secția IX $\mathrm{TBC}^{42}$, unde Grupul Operativ constituise un club de reeducare, condus de Ion Baniță ${ }^{43}$, în cadrul căruia Bartolomeu Anania susține câteva prelegeri literare despre autorii clasici - Ion Creangă, Mihail Sadoveanu, George Coșbuc, George Topîrceanu ${ }^{44}$.

Nemulțumită de activitatea clubului din secția IX TBC, conducerea penitenciarului îi ,prelucrează”, la începutul anului 1963, pe deținuți, criticând lipsa de entuziasm și angajament a

${ }^{39}$ Ibidem, dosar 13485, vol. 10 și 15, dosar FB 8825, dosar 10160, vol. 1 și 2.

${ }^{40}$ ACNSAS, fond Informativ, dosar 375778, vol. 1-5.

${ }^{41}$ Ibidem, dosar 1450, vol. 2, f. 1.

${ }^{42}$ ACNSAS, fond Documentar, dosar 10160, vol. 2, f. 214.

${ }^{43}$ Ibidem, f. 211.

${ }^{44}$ Ibidem, f. 216. 
Bartolomeu Valeriu Anania și reeducarea de la Aiud.

Noi contribuții documentare: dosarele Securității

acestora. Astfel, „la îndrumările educatorului politic, au fost deținuți care au răspuns provocator" ${ }^{45}$, printre care și „Anania Valeriu - Eu sunt călugăr şi nu mă interesează chestiunile politice, ci cu deosebire cele duhovnicești" ${ }^{46}$.

După 8 luni de activitate, evoluția clubului IX TBC era nesatisfăcătoare pentru administrație, care concluziona: „La secţia TBC, intelectualitatea a trădat încă o dată interesele legitime ale țăranilor și muncitorilor. Grupul acesta, care gravita în jurul lui Sandu Lăzărescu, Anania Valeriu, Chica Dumitru, Lae Lupu, frații Cazacu, Lambru Hristu și alții, a dovedit încă o dată ce cumplită este otrava legionară întrucât îi făceau să acționeze identic, deși nu erau organizați. În afară de acest intelectualism, mai afectau și o religiozitate demagogică, ținând în stimă mare epave mistice ca Ioan Iovan, Ionescu Traian, Medrea Mihai" 47 .

Lucrurile aveau să se schimbe în mai 1963, când colonelul Crăciun îl transferă pe Nicolae Grigorescu, fost primar legionar al orașului Târgoviște, din poziția de ,,ajutor de șef” la Clubul Mare în cea de șef al Clubului din secția IX, unde este ajutat de alţi 17 deținuți ${ }^{48}$.

Roadele muncii lui Nicolae Grigorescu, care avea un rol de prim-plan în acțiunea de reeducare, au început să apară încă din vara lui 1963. Astfel, în luna iulie își susțin „auto-analizele” 23 de deținuți, printre care și Bartolomeu Anania.

Înainte de a analiza conținutul declarației acestuia, merită subliniată evoluția la care ajunsese procesul reeducării la acel moment. Până în vara anului 1963 avuseseră loc deja momente decisive, precum: „prelucrarea și demascarea” liderilor legionari,

45 Ibidem, f. 217.

${ }^{46}$ Ibidem.

${ }^{47}$ Ibidem, f. 220.

48 Ion Baniță, Nicolae Nițulescu, Paul Păltânea, Vasile Purice, Nistor Nicolae, Bontaş Andrei, Ludu Alexandru, Ardeleanu Gheorghe, Grigoriu Alexandru, Negoescu Traian, Pricunda Ștefan, Tomșăneanu Marin, Szabo Ștefan, Popovici Dumitru, Spînu Marin, Ionescu S. Dumitru și Ruja Nicolae. ACNSAS, fond Documentar, dosar 10160, vol. 2, f. 252. 
de-a lungul anului 1962, în celulele 321 și $322^{49}$; popularizarea declarației de desolidarizare de Mișcarea Legionară a lui Radu Gyr (august 1962) ( $^{50}$, cu puternic impact asupra celorlalți deținuți; marile ședinţe ale reeducării, din ianuarie 1963, organizate cu ocazia eliberării a peste 500 de deținuți, la care au luat cuvântul, demascând organizația legionară, figuri cunoscute ale reeducării: Victor Biriş, Victor Vojen, Iosif Costea, Ion Dumitrescu-Borşa, Gheorghe Parpalac și Dumitru Stăniloae ${ }^{51}$.

Recapitulând, se poate afirma că reeducarea trecuse de „momentul critic”, demascarea organizației legionare de către majoritatea liderilor acesteia avusese loc, astfel că deținuților „obișnuiţi” nu le rămăsese decât acomodarea personală la noile realități.

Una din direcțiile de acțiune ale lui Nicolae Grigorescu, ca șef de club, a fost ,rezolvarea problemei religioase”, ce urma să se realizeze în două etape: mai întâi, separarea planului religios de cel politic; în a doua etapă s-a căutat să se demonstreze că religiile înseși nu sunt decât ,un opiu al popoarelor"52.

49 Coordonată de Victor Biriș, ajutat de Ştefan Minea, Victor Vojen, Gheorghe Parpalac, Dumitru Groza, Virgil Bordeianu, Iosif Costea și Petre Țocu, acțiunea de reeducare i-a vizat pe principalii lideri legionari din penitenciar, alături de alte câteva nume cu rezonanță în rândul deținuților, precum: Ilie Niculescu, Nistor Chioreanu, Alexandru Ghica, Augustin Bidianu, Iosif Costea, Victor Vojen, Radu Mironovici, Petru Țocu, Gheorghe Parpalac, Dumitru Groza, Ștefan Minea, Aurel Ibrăileanu, Constantin Savin, Florin Dumitrescu, Nicolae Dumitrescu, Virgil Bordeianu, Constantin Vasiliu, Gabriel Bălănescu, Ion Agapie, Liviu Brânzaş, Dumitru Stăniloae, Filon Lauric, Nelu Rusu, Cristofor Dancu, Radu Budișteanu, Aurel Călin, Stere Mihalexe, Nicolae Cojocaru, Luca Dumitrescu, Gheorghe Ungurașu, Andronic Bulhac, Iorgu Savin, Mircea Dumitrescu, Ion Dumitrescu Borșa. Activitatea din celulele 321 și 322 este documentată pe larg în dosarele documentare ale Grupului Operativ (ACNSAS, fond Documentar, dosar 12609, vol. 6, și dosar 13484 vol. 10), cât mai ales în dosarele personale ale lui Victor Biriș (ACNSAS, fond Informativ, dosar 310004, vol. 1 și 2), sau Iosif Costea (ACNSAS, fond Informativ, dosar 547429).

${ }^{50}$ ACNSAS, fond Informativ, dosar 184933, vol. 5, f. 1-93.

${ }^{51}$ ACNSAS, fond Informativ, dosar 310004, vol. 1, f. 27.

${ }^{52}$ Ibidem, f. 254. 
Bartolomeu Valeriu Anania și reeducarea de la Aiud.

Noi contribuții documentare: dosarele Securității

Auto-analiza lui Bartolomeu Anania s-a pliat pe prima direcție, respectiv critica creștinismului organizației legionare: „Problematica crimei legionare exclude cu desăvârșire ideea de jertfă creștină, așa numita jertfă nicadorică se plasează în plină erezie origenistă. Incercările de justificare a crimelor legionare prin citate biblice se întemeiază numai pe deformări și false interpretări de texte. Conceptul politico-mistic legionar este similar cezaropapismului catolic medieval și nu are nimic în comun cu ortodoxia. Solidaritatea cu organizația legionară care a făcut crime implică solidaritatea morală cu aceste crime și deci răspunderi. Legionarismul a denaturat și profanat elemente creștine pe care le-a folosit în scop politic. Codreanu e criminal și iniţiatorul unei școli de crime" $" 53$.

Mai departe, în toamna lui 1963, activitatea lui Bartolomeu Anania în reeducare avea să se lege tot de această problematică, a relației dintre creștinism și legionarism; Anania este transferat întrun club special condus tot de Nicolae Grigorescu și înființat pentru ,a duce muncă de lămurire pe lângă Ilie Niculescu"54.

Profesor la Academia Comercială, comandant al Corpului Răzleți $^{55}$ în timpul guvernării legionare, participant activ la evenimentele din ianuarie 1941 și închis între 1941 și 1964, Ilie Niculescu a fost unul din liderii legionari de prim rang, asupra căruia Grupul Operativ Aiud a dus o urmărire informativă intensă.

Procesul reeducării i-a obligat pe legionari, în special pe lideri, să reflecteze asupra erorilor și mișcării legionare. Răspunsurile și repoziționările au fost diverse, de la deținuţi care au „capitulat”, condamnând trecutul politic, până la cei care au recunoscut greșelile, dar s-au repoziționat identitar, oferind o cheie de lectură spirituală asupra trecutului.

Acesta este și cazul lui Ilie Niculescu. După șocul suferit în urma (auto)demascărilor lui Victor Biriş, Niculescu afirmă răspicat

\footnotetext{
${ }^{53}$ Ibidem, f. 287.

${ }^{54}$ Ibidem, f. 298.

${ }^{55}$ Corpul Răzleți era format din intelectualii legionari.
} 
că renunță total și categoric la activitatea (politică n.n.) prezentă și viitoare $^{56}$.

Replierea pe poziții creștine nu este bine primită de către Crăciun, care-1 suspectează pe Ilie Niculescu că, de fapt, își camuflează legionarismul în spatele ideilor creștine, presupunere la care contribuie și faptul că Niculescu afirmă că, din punct de vedere politic, el se situează pe poziții „social-creștine" ${ }^{57}$. La sugestia lui Nicolae Grigorescu, Crăciun le atribuie rolurile „lămuritoare” lui Ştefan Delavale, Nicolae Niţulescu și Valeriu Anania ${ }^{58}$.

Discutiile dintre Bartolomeu Anania și Ilie Niculescu au loc în octombrie-noiembrie 1963, simultan cu rostirea de către Nicolae Petrașcu, liderul legionarilor din țară, a declarației de desolidarizare de organizația legionară și asumare a reeducării (17-19

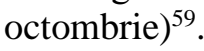

Discuțiile, ce impresionează prin profunzime teologică și culturală, se focalizează asupra incompatibilității dintre creștinism şi legionarism, Bartolomeu Anania subliniind contradicțiile ideologiei legionare care, deși pretins creștină, contrazice, în practică, morala creștină tocmai prin utilizarea crimei ca instrument politic. De asemenea, Bartolomeu Anania, utilizând distincţia credincios/rău credincios, abordează o problemă sensibilă, des întâlnită în rândul deținuților legionari, respectiv confuzia între identitatea politică și creștină, care-l determina pe Ilie Niculescu să considere că, desolidarizându-se de organizația legionară, și-ar abjura și credința creștină ${ }^{60}$.

Pentru a ilustra, cel puțin parțial, spiritul acestor discuții, merită citate câteva paragrafe relevante:

„Anania: Eu n-am fost, domnule doctor, în situația dvs., n-am avut nici numele dvs., nici funcția, nici rolul dvs. Până când să mă hotărăsc, am stat nopți întregi și m-am zvârcolit, m-am agitat și-mi venea greu să încep un nenorocit de articol la gazeta de perete, deși

${ }^{56}$ ACNSAS, fond Informativ, dosar 375778, vol. 5, f. 98.

${ }^{57}$ Ibidem, f. 156.

${ }^{58}$ Ibidem, f. 81.

${ }^{59}$ ACNSAS, fond Documentar, dosar 10160, vol. 2, f. 272.

${ }^{60}$ ACNSAS, fond Informativ, dosar 375778, vol. 5, ff. 98-106. 
Bartolomeu Valeriu Anania și reeducarea de la Aiud.

Noi contribuții documentare: dosarele Securității

mă știam că nu mai am nimic legionar în mine. [...] Eu sunt gata să fac tot ce pot, dar în materie religioasă, nu pot face concesii. Eu am constatat următoarele: Partidul pretinde de la un aderent al său să își însușească ideologia materialistă, cu alte cuvinte ateismul, iar statul nu pretinde unui cetățean un asemenea lucru. Ei nu vor să ne facă membri de partid și noi nu ne luăm decât o singură obligație față de stat. $[\ldots]$

Anania: Problema se pune așa. Dacă ajungem la conștiința adevărului asupra răului, am făcut primul pas. În ceea ce privește adevărul celălalt, unul vrea să-l găsească în materialism sau ateism, iar dvs. aveți adevărul suprem, ca și mine, în Dumnezeu și în acel adevăr rămânem, de fapt.

Niculescu: Al doilea nu mai există, gata, vă garantez. Și acum, după sarcina asta destul de plăcută, dar și dificilă, pe care o aveți de a demonstra necreștinătatea și anticreștinătatea Mișcării Legionare, să explicăm câteva probleme împreună. Dvs. ați spus, părinte, că legionarii au fost credincioși, dar niște rău credincioși și ați explicat și de ce acolo la club: cu slujirea la doi stăpâni. Al doilea element pe care 1-aţi adus: că am fost rău credincios, a fost trufia noastră manifestată în atitudinea noastră în ceea ce ne-am considerat că suntem cavalerii binelui în lupta împotriva răului. Și ați mers mai departe cu demonstrația că din această atitudine a apărut și mesianismul legionar și disprețul față de aproapele, adică am pus ura înaintea dragostei.

Anania: Este bine să ne oprim aici, că pe urmă avem mai multe idei. Ați pus dvs. această problemă la început: slujirea la doi domni și dvs. ați rezolvat-o și sunteți de acord că prin confuzia pe care am făcut-o între planul religios și cel politic legionar, am slujit la doi domni, am ajuns la răsturnarea acestor planuri.

Niculescu: $\mathrm{Nu}$, am sacrificat de multe ori planul superior pentru cel inferior. Așa-mi explic eu violențele și crimele care s-au săvârșit în Mișcarea Legionară. [...]

Niculescu: Eu am renunțat la legionarism în favoarea planului creștin. Deci eu nu sunt suspendat, dar dincoace, unde mi se cere aceeaşi participare care mi s-a cerut în garda de fier, aici e problema. 
Anania: Carevasăzică rămăseserăm la atitudinea față de trecut și prezent. $\mathrm{Nu}$ este aceeași apartenență a cetățeanului în orânduirea socialistă cu apartenența unui legionar la Mișcarea Legionară: că nu e vorba de o aderare integrală la comunism. Adică mă postez rezervat cu anumite puncte doctrinare, acum este concepția despre lume și viaţă și înțeleg să ader să sprijin acele elemente care mi se par bune. Fără îndoială că acesta este însă cetăţeanul ideal. [...]

Anania: Atât cât biserica nu aderă la comunism, nu trebuia să adere nici la idealism. [...]

Anania: Și aici trebuie să mă credeți pe mine, că nu avem alte surse, dar aș vrea încă o dată să fie evident pentru dvs., mai cu seamă că în materie de credință nu pot face tranzacție. Sau atunci când Niki Constantinescu ${ }^{61}$ spune că e conștient că-și jertfește mântuirea, dar o jertfește pentru neam. Eu vin și spun că nu există în toată învățătura creștină, nici un fel de temei, prin care mântuirea să poată fi sacrificată, el atunci încetează de a mai fi creștin. Și deci crima a fost făcută de un păgân și nu de un creștin. [...]

Anania: Din punct de vedere al credinței, Mișcarea Legionară a fost mai primejdioasă pentru spiritul creștin, decât comunismul. Pentru că Mișcarea Legionară, ridicându-se în numele creștinismului, dar introducând în viața mea puncte alterate și punându-mă în situația de a fi uneori chiar eretic, mă pune în situația de a-mi altera creștinismul din mine, de a-mi altera doctrina, pe câtă vreme comunismul mi se prezintă ca adversar din început, îmi combate această doctrină, pe care eu o am în mine, dar nu mi-o alterează. El nu se infiltrează în creștinismul meu, ca apoi să mi-l altereze, ci îl tăgăduiește pe plan"62.

Rolul și activitatea lui Bartolomeu Anania aveau să fie apreciate de către Nicolae Grigorescu, după cum reiese dintr-o notă din 2 decembrie 1963 adresată colonelului Crăciun: „Anania şi-a

61 Alături de Ion Caranica și Doru Belimace, Nicolae Constantinescu a făcut parte din echipa ,Nicadorilor”, care 1-a asasinat pe prim-ministrul I. G. Duca pe peronul gării din Sinaia în decembrie 1933.

${ }^{62}$ ACNSAS, fond Informativ, dosar 375778, vol. 5, ff. 81-116. 
Bartolomeu Valeriu Anania și reeducarea de la Aiud.

Noi contribuții documentare: dosarele Securității

îndeplinit sarcina pe care i-am împărtășit-o pe îndelete în pauzele din primele zile ale activității clubului: să dezvăluie lui Niculescu contradicțiile și confuziile din ideologia legionară, precum și inconsecventele din faptele legionare, privite din punctul de vedere al așa-zisului fond creștin al Mișcării Legionare. Anania Valeriu șia făcut datoria cu multă competență și căldură, izbutind să prăbușească tot eșafodajul spiritual-legionar al lui Ilie Niculescu, astfel că munca de lămurire asupra celor ce trebuie să cuprindă declarația acestuia, s-a ușurat mult. Anania a contribuit efectiv și cu rezultate pozitive în toate greutățile pe care le-am întâmpinat la Ilie Niculescu cu privire și la alte aspecte ce au trebuit cuprinse de acesta în lucrarea sa autobiografică. În concluzie consider că Anania Valeriu este un element foarte pozitiv în munca pe care a desfășurat-o, trecând peste starea sa fizică" ${ }^{\prime 63}$.

În ceea ce privește rezultatul concret al activității lui Bartolomeu Anania, reflectate în declarațiile publice ale lui Ilie Niculescu în cadrul ședințelor de la club, se observă o influență directă, liderul legionar asumându-și lămuririle teologice propuse de către Anania. Într-o declarație autobiografică amplă, în care descrie detaliat activitatea avută în detenție începând din 1941, Ilie Niculescu abordează și problema relației dintre creștinism și legionarism. Poziția sa ${ }^{64}$, deși afirmată în cadrul ședințelor de club, frapează prin caracterul creștin, desprins de influențe ideologice:

„Decenii de-a-rândul ne-am hrănit cu conștiința că suntem mai mult decât un partid politic, și chiar mai mult decât o școală: că suntem o religie și am acordat ideologiei și luptei noastre atributele adevărurilor absolute. [...] Acum trebuie să pricepem că nu comunitatea neamului, ci cea a bisericii operează mântuirea omului și că pretenţia mesianismului nostru legionar nu a fost altceva decât o încercare de a ne substitui funcțiunii soteriologice a bisericii.

Trebuie să ne dăm seama că, prin politizarea patronajului arhanghelului Mihail, noi i-am limitat cultul - aruncându-1 în

\footnotetext{
${ }^{63}$ Ibidem, f. 124.

${ }^{64}$ Caracterul inedit și conformitatea cu învățătura Bisericii argumentează citarea in extenso a unor fragmente.
} 
subversivitate, odată cu noi - că i-am deformat sensul moral, transformându-i simbolul spiritual al sabiei în armă de violenţă și asasinat; că i-am degradat imaginea iconografică, transformând-o în insignă politică.

Măcar acum trebuie să recunoaștem că această falsă viziune asupra creștinismului ne-a creat orgoliul de a ne considera o cruciadă modernă și că nu numai că n-am izbutit să promovăm o linie de înaltă trăire religioasă, așa cum năzuiam, dar ne-am pomenit că nefericita noastră istorie a fost străbătută de un curent morbid înlăuntrul căruia s-au petrecut numeroase acte de violenţă, mergând până la crimă.

E momentul să știm că asasinatul, chiar când este făcut în numele neamului, nu poate fi justificat cu texte biblice, că jertfa legionară, mergând până la sacrificarea mântuirii proprii, nu poate fi o jertfă creștină, ci, dimpotrivă, anularea însăşi a calităţii de creștin; că, prin enunțarea și însumarea jertfei nicadorice, ne-am plasat de-a dreptul în plină erezie origenistă, oficial condamnată de biserica universală, prin hotărâre ecumenică.

Astăzi e necesar să mărturisesc că amestecarea planului religios cu cel politic a dus, până la urmă, la sacrificarea celui dintâi, că prin aceasta am făcut un rău serviciu integrității doctrinare a fiecăruia dintre noi și că, deși am fost credincioși, n-am fost totdeauna bine credincioși, ci adeseori rău credincioşi.

În ceea ce mă privește, îmi dau astăzi seama de toate acestea şi declar că nu înțeleg să fac din credința mea religioasă nici un fel de instrument de luptă politică" 65 .

După episodul „Ilie Niculescu”, Bartolomeu Anania mai apare în procesul reeducării abia pe final, respectiv în vara anului 1964, în legătură cu o temă ,sensibilă”, cu reverberații memoriale puternice, și anume „Cartea reeducării”. Așa cum am menționat anterior, colonelul Crăciun a fost interesat, alături de „succesul” reeducării, de raportarea și instrumentalizarea propagandistică a acestui succes. Astfel, din cele peste 11.000 de declarații semnate de deținuți în cadrul cluburilor de reeducare, colonelul Crăciun, cu

${ }^{65}$ ACNSAS, fond Informativ, dosar 375778, vol. 1, ff. 294-294 verso. 
Bartolomeu Valeriu Anania și reeducarea de la Aiud.

Noi contribuții documentare: dosarele Securității

ajutorul unui comitet editorial compus din deținuți, elaborează câteva volume intitulate sugestiv: „Isprăvi de bandiți în odăjdii”, „Un huligan de odăjdii - Viorel Trifa”, „Spionaj-trădare”, „Crimă, asasinat, teroare”, „Privire critică asupra organizației legionare"66.

Cea mai importantă lucrare, rămasă în memoria(listica) Aiudului sub denumirea „Cartea reeducării”, a fost intitulată „Despre organizația legionară”. Primul volum, dedicat istoriei organizației legionare, de la fondare și până la guvernarea legionară, se dorea a fi, de fapt, o „contra-istorie” a Mișcării Legionare, scrisă în stil demascator tocmai de către deținuți legionari. Prin cel de-al doilea volum, dedicat activității legionarilor în temniţele comuniste, colonelul Crăciun urmărea construirea unei „anti-memorii”, o memorie alternativă a Gulagului, scrisă din perspectiva „regimului”, prin care deținuții își asumau activitatea criminală din închisori (Pitești, Gherla, Tg. Ocna, Canal, Ocnele Mari, minele de Plumb), totul culminând cu procesul reeducării. Aceasta era prezentată ca un act de binefacere din partea regimului, care dorea să le ofere foștilor legionari „șansa reabilitării”, „ofertă” condiţionată de (auto)demascarea propriului trecut și asumarea încadrării în noua ordine social-politică.

Alături de scopul imediat pentru care a fost creată, respectiv „de a fi folosită eventual împotriva fugarilor de peste graniță"67, elaborarea acestei lucrări urmărea două obiective majore: pe de o parte, reprezenta „medalia victoriei” pentru Grupul Operativ, care putea ilustra conducerii Ministerului de Interne și Partidului succesul reeducării, iar pe de altă parte, era un instrument de șantaj pentru deținuții legionari și în special a ,autorilor”, a căror contribuție la „succesul” reeducării putea fi probat.

Pentru a da greutate demersului, colonelul Crăciun are interesul ca printre semnatari să se afle personalitățile politice și culturale ale Aiudului. Comitetul editorial era compus din „coordonatorul lucrării” - Stere Mihalexe, ajutat de cinci redactori, printre care şi Nicolae Grigorescu, alături de un „responsabil”

${ }^{66}$ ACNSAS, fond Documentar, dosar 13485, vol. 15, f. 226.

${ }^{67}$ Ibidem. 
artistic - Nicolae Ruja ${ }^{68}$. De asemenea, au semnat lucrarea 64 de colaboratori, printre care se găsesc numele majorității liderilor legionari - Augustin Bidianu, Bulhac Andronic, Nistor Chioreanu, Dragoș Hoinic, Radu Mironovici, Nicolae Orbulescu, Zaharia Pană, Nicolae Pătrașcu, Aurel Popa, Radu Tase, Iorgu Savin ${ }^{69}$. Nu în ultimul rând, caseta editorială cuprinde numele a 12 ilustratori, 34 de graficieni, 3 compactori și 5 deținuți responsabili de basorelieful coperților, printre care și Radu Mironovici ${ }^{70}$.

Numele lui Bartolomeu Anania apare printre colaboratorii cărții; lângă semnătură, el precizează și paginile din lucrare pe care le-a semnat ${ }^{71}$. Această mențiune, singulară printre toate celelalte semnături, oferă cercetătorului șansa să identifice cu acuratețe materialul redactat de Bartolomeu Anania. Numărând 4 pagini, textul lui Bartolomeu Anania, intitulat „Teoreticianul suferinței nu suportă suferința", abordează, într-un limbaj ce respectă terminologia specifică reeducării, perioada detenției lui Corneliu Codreanu din 1938, autorul acuzându-1 pe acesta de faptul că refuză să-și asume suferința pe care a pretins-o de la ceilalți legionari: „Înspăimântat de primejdia ce se ridică asupra vieții lui, Codreanu se gândește acum că orice activitate a legionarilor de afară ar putea să-i agraveze situația. Și el, Căpitanul, pentru care o întreagă legiune este gata să-și continue lupta, să bată, să schingiuiască, să ucidă - ordonă din închisoare încetarea oricărei activități și intrarea legionarilor «la zece metri sub pământ». Stupoare, anarhie, consternare, torsiuni sufletești. Teoreticianul suferinței nu suportă suferința! ${ }^{72 "}$

Ultima referință la activitatea lui Bartolomeu Anania în reeducare se referă la ședința organizată la sfârșitul lunii iulie 1964, cu ocazia eliberării deținuţilor. În raportul dedicat acestui eveniment, colonelul Crăciun menţionează că ,au vorbit un număr de 24 de legionari din cei 80 înscriși la cuvânt: Nicolae Petrașcu,

${ }^{68}$ ACNSAS, fond Documentar, dosar 10160, vol. 1, f. 3.

${ }^{69}$ Ibidem.

${ }^{70}$ Ibidem, f. 4.

${ }^{71}$ Ibidem, f. 3v.

${ }^{72}$ Ibidem, ff. 283-286. 
Bartolomeu Valeriu Anania și reeducarea de la Aiud.

Noi contribuții documentare: dosarele Securității

Nistor Chioreanu, Mircea Nicolau, Constantin Răileanu, Constantin Savin, Gheorghe Ungurașu, Radu Mironovici, Constantin Coniac, Dumitru Banea, Dancu Cristofor, Valeriu Anania, Nicolae Ruja și altii.

Aceștia, în cuvântul lor, au adus mulțumiri conducerii statului și partidului nostru pentru clemența ce le-a acordat-o, angajându-se să fie alături de popor și de stat în toate acțiunile, pentru prosperitatea pe mai departe a țării noastre"73. In textul raportului, colonelul Crăciun citează doar o parte din declarațiile celor menționați, precum Nicolae Petrașcu, Nistor Chioreanu, Mircea Nicolau, Constantin Savin, Nicolae Ruja, lipsind referința la cuvintele spuse de Bartolomeu Anania ${ }^{74}$.

\section{Concluzii}

Precizate încă din introducere, ,limitele” prezentei analize impun precauții în elaborarea unor concluzii ,definitive”, scopul principal al articolului fiind de a aduce contribuții la înțelegerea unui subiect controversat la nivelul memoriei Gulagului. Tocmai de aceea, se impune pe viitor o analiză aprofundată a literaturii memorialistice referitoare la activitatea lui Bartolomeu Anania în reeducare (contextul, motivațiile și idiosincraziile politice ale creatorilor de discurs memorial). De asemenea, un pericol de care trebuie ținut cont în emiterea unor ,verdicte memoriale" este capcana de ,tribunal al memoriei”, în care cercetătorul/istoricul este chemat să „împartă" dreptatea unuia sau altuia din memorialiști. Acest lucru e valabil cu atât mai mult în cazul reeducării de la Aiud unde, spre deosebire de fenomenul omonim de la Pitești în care violența extremă a absolvit în întregime deținuții care au fost acolo, aparentul umanism al administrației, regimul de detenție şi metodele folosite au creat tensiuni între deținuți. Atitudinile și

73 ACNSAS, fond Documentar, dosar 13485, vol. 15, f. 220.

${ }^{74}$ Ibidem, ff. 220-224. 
pozițiile atât de diverse, precum și gradele diferite de acceptare sau refuz ale reeducării au spart unitatea memoriei ${ }^{75}$.

Tocmai de aceea, efortul de a utiliza memorialistica ca pe o sursă unitară de reconstituire a reeducării e plină de pericole. Încercarea de a extrage din fiecare mărturie câte ceva pentru a finaliza puzzle-ul și de a ,împăca" mărturii contradictorii, se poate dovedi falimentară. Astfel, în cazul reeducării de la Aiud, se poate sesiza o tensiune la nivelul literaturii memorialistice - nu avem o memorie unitară a reeducării, ci multiple povești ale memoriei despre reeducare, versiuni care sunt influențate de contextul istoric, apartenența ideologică și motivația memorialistului.

Referindu-ne strict la perspectiva pe care documentele Securităţii ne-o oferă asupra activității lui Bartolomeu Anania în reeducare, putem afirma, sub rezerva unor cercetări documentare ulterioare care pot completa nivelul de cunoaștere, că acesta a avut un rol secundar, aspect determinat și de impactul marginal sub aspect politic pe care Bartolomeu Anania 1-a avut în cadrul Mișcării Legionare (fost membru al organizației de tineret, Frăția de Cruce, identitate de care acesta s-a detaşat încă din anii '40). Pentru conducerea Grupului Operativ Aiud, organismul de Securitate care coordona reeducarea, Bartolomeu Anania nu a fost o miză ,principală” în procesul reeducării, colonelul Crăciun și ofițerii săi concentrându-se asupra deținuților cu grade și funcții în organizația legionară.

Astfel, după ce trece prin ,tiparul reeducărilor” de la Club, Bartolomeu Anania este utilizat de către conducerea închisorii, la sugestia lui Nicolae Grigorescu, șeful clubului de reeducare, la „prelucrarea" lui Ilie Niculescu, căruia Bartolomeu Anania îi clarifică raporturile dintre creștinism și legionarism, subliniind contradicțiile dintre credința creștină autentică și concepția religioasă a Mișcării Legionare.

75 Dragoș URSU, „Memoria reeducării din penitenciarul Aiud”, în ClaudiaFlorentina DobRe, Valeriu ANTONOVICI (coord.), Prezentul comunismului: memorie culturală și abordări istoriografice, Oradea, Ratio et Revelatio, 2016. 
Bartolomeu Valeriu Anania și reeducarea de la Aiud.

Noi contribuții documentare: dosarele Securității

Referitor la contribuția lui Bartolomeu Anania la „cartea reeducării”, documentele argumentează rolul marginal pe care el 1-a avut, fiind unul din cei 135 de contributori ai cărții, rolul de „coordonatori-editori” ai lucrării avându-1 alţi deținuţi. În ceea ce privește contribuția efectivă, este vorba de un material de 4 pagini (dintr-o lucrare ce număra 826 de pagini) dedicat perioadei de detenție carlistă (1938) a lui Corneliu Codreanu, pe care Bartolomeu Anania îl redactează folosind terminologia specifică reeducării.

$\cos 80$

\section{Bibliografie}

\section{A. IZVOARE SCRISE}

1. Arhiva Consiliului Național pentru Studierea Arhivelor Securității (ACNSAS): Anania Valeriu - fond Informativ, dosar 888, dosar 930, dosar 1450 (5 vol.); Anania Dumitru - fond Informativ, dosar 491900 ( 2 vol.); Chioreanu Nistor - fond Informativ, dosar 233979 (10 vol.); Niculescu Ilie - fond Informativ, dosar 375778 (5 vol.); Victor Biriș - fond Informativ, dosar 310004, vol. 1 și 2; Iosif Costea - fond Informativ, dosar 547429

2. Fond Documentar, dosarele 3463, 7368, 8826 (3 vol.), 10160 (2 vol.), 12163, 12581, 12609 (6 vol.), 13088, 13341 (2 vol.), 13481, 13482 (6 vol.), 13483 (3 vol.), 13484 (14 vol.), 13485 (15 vol.).

\section{B. LITERATURĂ SECUNDARĂ}

\section{Memorialistică}

3. AnANIA, Valeriu, Memorii, Iași, Edit. Polirom, 2008.

4. ANDRONESCU, Demostene, Reeducarea de la Aiud, București, Edit. Christiana, 2009.

5. ANTOHE, Ion, Răstigniri în România după Ialta, București, Edit. Albatros, 1995.

6. BARTOLOMEU, Mitropolitul, Corupția spirituală, ediție îngrijită de Radu Preda şi Bogdan Ivanov, Cluj-Napoca, Edit. Eikon, 2011.

7. CARAZA, Grigore, Aiud însângerat, Iași, Edit. TipoMoldova, 2013.

8. CĂLINESCU, Puiu, Temerarii, Constanța, Edit. Metafora, 2004. 
9. CÂRJA, Ion, Amintiri din infern, vol. 1 și 2, New York, Acţiunea românească, 1972.

10. ChIOREANU, Nistor, Morminte vii, Iași, Edit. Institutul European, 1992.

11. MARINESCU, Aurel Sergiu, O contribuție la istoria exilului românesc. Biserica Ortodoxă Română în străinătate, în exil, în diaspora, București, Edit. Vremea, 2004.

12. VoINEA, Octavian, Masacrarea studenții române în închisorile de la Pitești, Gherla și Aiud, București, Edit. Majadahonda, 1996.

\section{Studii}

13. URSU, Dragoș, „Memoria reeducării din penitenciarul Aiud”, în Claudia-Florentina DoBRE, Valeriu ANTONOVICI (coord.), Prezentul comunismului: memorie culturală și abordări istoriografice, Oradea, Ratio et Revelatio, 2016. 